\title{
SEASONAL VARIATION IN LEAF EXTRACTS OF DENDROCALAMUS STRICTUS SPS-AS REFLECTED IN DIFFERENTIAL EXPRESSION OF SOLUBLE BIOSYNTHATES
}

\section{SAIRA MALIK, SAS BISWAS, SYED MANSOOR \& DHIRAJ KUMAR}

Forest Research Institute, Dehradun, India ABSTRACT

A variation within species is the reflection of its genotype and its interaction with the environment. Seasonal cycles of temperature, photoperiod, light intensity, relative humidity and rainfall exert a pronounced control over the various biosynthetic pathways and provide it with a pattern to which developmental changes are physiologically locked. The present study carried out on the germplasm of D.strictus (raised via offsets collected from different eco-geographic zones of India with an altitudinal sprawl of 225-1367 mts) revealed substantial variation in biochemical characteristics in different seasons March-May, June-Aug and Dec-Jan.

Significant inter-accession variation was observed among D.strictus sps. The maximum mean value of chlorophyll content (2.551 $\mathrm{mg} / \mathrm{gm})$, total soluble protein (18.02 $\mathrm{mg} / \mathrm{gm})$ and soluble sugars $(25.24 \mathrm{mg} / \mathrm{gm})$ were observed in A35 from Hoshiarpur,India. The average value of phenol content among the accessions was found to be $0.20 \mathrm{mg} / \mathrm{gm}$. The accession A32 (0.3 mg/gm) from Kahanpur registered maximum mean value for phenol content. Overall significant seasonal differences in biochemical characteristics reflect the influence of extraneous factors underscoring the reciprocal relationship between genotype and environmental factors. The best association between season* genotypes with respect to photosynthates was mostly observed in the months of July-August in accessions from Punjab (A35).

KEYWORDS: D.Strictus, Diversity, Germplasm, Biochemical Variation

Received: Jun 05, 2017; Accepted: Jun 25, 2017; Published: Jul 03, 2017; Paper Id.: IJBRAUG20171

\section{INTRODUCTION}

Both anthropogenic activities such as over exploitation compounded with gregarious flowering in D.strictus have resulted in major depletion of its growing area and diversity, thus there is an urgent need to increase its plantation with high productivity, which can be achieved through ascertaining the potential species, analysis of genetic variability among traits and association of a particular character in relation to other traits contributing to yield (Mary and Goplan, 2006). The population level genetic diversity in D. strictus is still at its infancy stage. Efforts to quantitatively assess genetic diversity would assist in proper selection of desired genotype for bamboo improvement programs. Germplasm characterization is an important link between conservation and utilization of plant genetic resources. Knowledge of genetic diversity and relationships among a set of germplasm and the potential merit of the genetic diversity would be beneficial in all phases of improvement, optimizing hybridization and selection procedures, besides understanding the cohorts in the event of sporadic, erratic and disjunct flowering in this bamboo species. The wide distribution and adaptability of $D$. strictus encompasses a great diversity which is expected to be reflected in its genetic constitution, hence identification and characterization of its genetic resources assumes great significance. The present work purports to study diversity in D. strictus germplasm using 
biochemical traits.

\section{MATERIALS AND METHODS}

Twenty different accessions of $D$. strictus were selected from Dendrosetum at Forest Research Institute (FRI) Dehradun, harboring D. strictus clones collected from different eco-geographical zones of India in the year 2008 under the project "Bamboo improvement for rural and tribal communities, integrating new technologies" funded by National Bamboo Mission, New Delhi. Table 1.

Table 1

\begin{tabular}{|c|c|l|c|c|c|c|}
\hline Serial. No & Accession code & Provenances & Latitude $\left.{ }^{\circ} \mathbf{N}\right)$ & Longitude $\left({ }^{\circ} \mathbf{E}\right)$ & Altitude \\
\hline 1 & A-1 & Biyasi & $30^{\circ} 44^{\prime}$ & $78^{\circ} 27^{\prime}$ & 1352 \\
\hline 2 & A-5 & Devprayag & $30^{\circ} 15^{\prime}$ & $78^{\circ} 6^{\prime}$ & 830 \\
\hline 3 & A-7 & Mansadevi & $26^{\circ} 92^{\prime}$ & $78^{\circ} 15^{\prime}$ & 444 \\
\hline 4 & A-8 & Haridwar & $26^{\circ} 96^{\prime}$ & $78^{\circ} 16^{\prime}$ & 315 \\
\hline 5 & A-10 & Shyampur & $26^{\circ} 74^{\prime}$ & $78^{\circ} 11^{\prime}$ & 310 \\
\hline 6 & A-11 & Sahaspur & $26^{\circ} 73^{\prime}$ & $78^{\circ} 05^{\prime}$ & 311 \\
\hline 7 & A-13 & Kalsi & $30^{\circ} 32^{\prime}$ & $78^{\circ} 03^{\prime}$ & 510 \\
\hline 8 & A-16 & Bhogpur & $30^{\circ} 1^{\prime}$ & $77^{\circ} 28^{\prime}$ & 255 \\
\hline 9 & A-17 & Pinjore & $30^{\circ} 79^{\prime}$ & $76^{\circ} 91^{\prime}$ & 550 \\
\hline 10 & A-18 & Thadugarh & $30^{\circ} 73^{\prime}$ & $76^{\circ} 78^{\prime}$ & 225 \\
\hline 11 & A-19 & Seonthi & $30^{\circ} 2^{\prime}$ & $74^{\circ} 23^{\prime}$ & 250 \\
\hline 12 & A-20 & Kurukshetra & $29^{\circ} 6^{\prime}$ & $77^{\circ} 04^{\prime}$ & 222 \\
\hline 13 & A-23 & Hissar & $29.15^{\prime}$ & $75.71^{\prime}$ & 210 \\
\hline 14 & A-28 & Ropar & $30^{\circ} 96^{\prime}$ & $76^{\circ} 53^{\prime}$ & 262 \\
\hline 15 & A-32 & Kahanpur & $26^{\circ} 46^{\prime}$ & $80^{\circ} 33^{\prime}$ & 228 \\
\hline 16 & A-35 & Hoshiarpur I & $31^{\circ} 53^{\prime}$ & $75^{\circ} 92^{\prime}$ & 296 \\
\hline 17 & A-36 & Hoshiarpur II & $31^{\circ} 52^{\prime}$ & $75^{\circ} 90^{\prime}$ & 294 \\
\hline 18 & A-38 & Dasuya & $31^{\circ} 82^{\prime}$ & $75^{\circ} 66^{\prime}$ & 240 \\
\hline 19 & A-40 & Jhelwa & $31^{\circ} 5^{\prime}$ & $75^{\circ} 6^{\prime}$ & 250 \\
\hline 20 & A-88 & Andhra Pradesh & $17^{\circ} 36^{\prime}$ & $78^{\circ} 47^{\prime}$ & 536 & AP \\
\hline
\end{tabular}

The following (in bold) biochemical constituents were studied and quantified in three seasons viz., summer (March -May), rainy (June-August), winter (December - February) in three replicates (ramets) of each accession for two years.

\section{Total Chlorophyll Content}

The content of chlorophyll a and b was estimated using the method given by Holm (1954). The total chlorophyll content and chlorophyll $a / b$ ratio were also derived.

$100 \mathrm{mg}$ fresh leaf material was homogenized with $1 \mathrm{ml}$ of $80 \%$ chilled acetone in mortar and pestle over ice pack and centrifuged at $2000 \mathrm{rpm}$ for 10 minutes. The supernatant was elicited with $80 \%$ acetone and the absorbance was recorded in 644, 662 and 440.5 NM wavelengths spectrophotometrically in PC based UV-VIS spectrophotometer (Perkin Elmer Lambda 2S, German made) against $80 \%$ acetone. The formula as given by Holm was used to compute the chlorophyll content.

\section{Total Soluble Protein}

The total proteins from the leaves of 3 replicates expressed in $\mathrm{mg} / \mathrm{g}$ fresh weight of leaves under all treatments was estimated by the method given by Lowry (1951). $0.1 \mathrm{~m}$ Tris-buffer (pH 7.5) in a cold, grinding medium with sodium 
dodecyl sulfate (3\%) and polyvinyl pyrrolidine (3\%) followed by centrifugation at $2000 \mathrm{rpm}$ for $10 \mathrm{minutes} .0 .1 \mathrm{ml}$ supernatant was taken and $0.9 \mathrm{ml}$ extraction buffer was added to it along with $5 \mathrm{ml}$ mixture of $2 \% \mathrm{Na}_{2} \mathrm{Co}_{3}$ in $0.1 \mathrm{~N} \mathrm{NaOH}$ and $0.5 \% \mathrm{CuSO}_{4} \mathrm{H}_{2} \mathrm{O}$ in $1 \%$ sodium potassium tartarate solution, in the ration 50:1. The tubes were kept for 30 min to allow color development. Absorbance was measured at $660 \mathrm{~nm}$ against reagent blank in PC based UV-VIS spectrophotometer (Perkin Elmer Lambda 2S, German made). The standard curve was prepared with Bovine Serum Albumin (BSA).

\section{Total Soluble Sugars}

The estimation of total sugars was carried out as per the method given by Dubois et al., (1956). $0.2 \mathrm{ml}$ ethanol extract diluted with $0.8 \mathrm{ml}$-distilled water was treated with $1 \mathrm{ml}$ of $5 \%$ phenol and $5 \mathrm{ml}$ concentrated sulphuric acid. The mixture was allowed to cool down to room temperature before finally recording the absorbance at $490 \mathrm{~nm}$ in UV/Vis spectrophotometer, (model Perkin Elmer, Lambda) against reagent blank in which the diluted extract was replaced by 1 $\mathrm{ml}$ distilled water. The standard curve was prepared by using D- Glucose concentrations. Total soluble sugar content was expressed as $\mathrm{mg} / \mathrm{g}$ dry weight of a leaf.

\section{Total Phenol Content}

Total phenol content in the leaf samples was read from the reference curve prepared by using p-Cresol concentrations and expressed in mg/g dry weight of leaves. The ANOVA was carried out using Genstat version 3.2 as per the designed experiment i.e. randomized block design. The source of variation was accession, seasons and accession $\mathrm{x}$ season interaction. The F value, thus obtained was compared with the tabulated values at the $0.1 \%$ level of significance and respective degrees of source and error.

The linear relationship between biochemical parameters were studied with the help of Minitab release 11.2 using Karl Pearson's simple correlation coefficients.

\section{RESULTS}

\section{Total Biochemical Content}

As evident from Table 2, Significant inter accession variation at the $5 \%$ level was recorded in total soluble protein content with A35 from Hoshairpur recording $(18.02 \mathrm{mg} / \mathrm{g})$ of total soluble protein content followed by A13 (16.51 mg/g) from Kalsi. The total protein content among the accessions varied from $12.09 \mathrm{mg} / \mathrm{g}$ to $18.02 \mathrm{mg} / \mathrm{g}$. The accession A35 (Hoshiarpur) registered the maximum amount of sugar content $(25.24 \mathrm{mg} / \mathrm{g}$ ) followed by accession $40(23.26 \mathrm{mg} / \mathrm{gm})$ (Hoshairpur II).Similarly variation in the concentration of Chlorophyll pigment content across the accession is evident with maximum $2.55 \mathrm{mg} / \mathrm{g}$ observed in Hoshairpur A35 accession, however highest chlorophyll b pigment is found in A5.The secondary metabolites such as phenolics exhibited significant variation with accession A32 Kahanpur (Punjab) recording the maximum yield followed by A40 from Jhelwa (Punjab).The range varied from A 32 $(1.49 \mathrm{mg} / \mathrm{g})$ to A23 (0.371 mg/g). The mean values for various biochemical components are given in Table (2).

Table 2: Biochemical Composition in a Score Selected Accessions of D.Strictus

\begin{tabular}{|c|c|c|c|c|c|c|c|}
\hline Accessions & $\begin{array}{c}\text { Total } \\
\text { Chlorophylls } \\
(\mathbf{M g} / \mathbf{G})\end{array}$ & $\begin{array}{c}\text { Chlorophyll } \\
\text { “A”(Mg/G) }\end{array}$ & $\begin{array}{c}\text { Chlorophyll } \\
\text { 'B”(Mg/G) }\end{array}$ & $\begin{array}{c}\text { Chlorophyll } \\
\text { A/B }\end{array}$ & $\begin{array}{c}\text { Total } \\
\text { Protein } \\
(\mathbf{M g} / \mathbf{G})\end{array}$ & $\begin{array}{c}\text { Total } \\
\text { Sugars } \\
(\mathbf{M g} / \mathbf{G})\end{array}$ & $\begin{array}{c}\text { Total } \\
\text { Phenol } \\
(\mathbf{M g} / \mathbf{G})\end{array}$ \\
\hline A1 & 2.141 & 1.271 & 0.870 & 1.76 & 13.88 & 18.49 & 0.204 \\
\hline A5 & 2.309 & 1.420 & $\mathbf{0 . 8 8 9}$ & 1.83 & 12.58 & 21.01 & 0.14 \\
\hline
\end{tabular}




\begin{tabular}{|c|c|c|c|c|c|c|c|}
\hline A7 & 2.304 & 1.508 & 0.832 & 1.85 & 12.45 & 19.22 & 0.24 \\
\hline A8 & 2.229 & 1.614 & 0.614 & 3.60 & 14.98 & 21.48 & 0.11 \\
\hline A10 & 2.041 & 1.344 & 0.697 & 1.97 & 12.95 & 15.58 & 0.24 \\
\hline A11 & 1.343 & 0.869 & 0.474 & 2.13 & 15.2 & 19.07 & 0.22 \\
\hline A13 & 2.51 & 1.684 & 0.826 & 2.53 & 16.51 & 22.25 & 0.21 \\
\hline A16 & 1.579 & 1.067 & 0.512 & 2.39 & 15.43 & 19.68 & 0.10 \\
\hline A17 & 2.011 & 1.446 & 0.566 & 2.68 & 14.22 & 18.54 & 0.25 \\
\hline A18 & 1.857 & 1.392 & 0.464 & 3.47 & 15.92 & 19.63 & 0.02 \\
\hline A19 & 1.013 & 0.668 & 0.346 & 2.10 & 12.35 & 18.4 & 0.22 \\
\hline A20 & 1.543 & 0.969 & 0.574 & 2.06 & 15.01 & 17.19 & 0.09 \\
\hline A23 & 1.723 & 1.214 & 0.509 & 3.00 & 14.1 & 21.03 & 0.07 \\
\hline A28 & 1.913 & 1.144 & 0.780 & 1.73 & 15.03 & 16.1 & 0.24 \\
\hline A32 & 1.692 & 1.129 & 0.563 & 2.64 & 15.46 & 21.32 & 0.30 \\
\hline A35 & 2.551 & 1.742 & 0.809 & 2.44 & 18.02 & 25.24 & 0.12 \\
\hline A36 & 1.84 & 1.148 & 0.692 & 2.09 & 15.12 & 18.44 & 0.26 \\
\hline A38 & 1.971 & 1.447 & 0.524 & 3.74 & 15.82 & 18.89 & 0.25 \\
\hline A40 & 1.956 & 1.392 & 0.563 & 3.77 & 12.09 & 23.26 & 0.264 \\
\hline A88 & 1.756 & 1.109 & 0.647 & 1.72 & 13.27 & 21.77 & 0.155 \\
\hline Mean & 1.9 & 1.28 & 0.638 & 2.5 & 14.5 & 19.8 & 0.20 \\
\hline Significance & $* * *$ & $* * *$ & $* * *$ & NS & $* * *$ & $* * *$ & $* * *$ \\
\hline Critical Difference & 0.3445 & $\mathbf{0 . 3 3 3}$ & 0.238 & 1.67 & 1.786 & $\mathbf{3 . 5 1 1}$ & $\mathbf{0 . 0 3 4}$ \\
\hline
\end{tabular}

$* * *$ - Significance at 0.1\%,** - Significance at 1\%.* Significance at 5\%, NS - Non Significant.

Significant interaction Table 3 between season and accession is reflected in total soluble sugar and protein content. The best interaction was observed in accession A18 (21.27 mg/g) from Thadugarh yielding maximum amount of total protein in rainy season viz., July -August. The month viz., Dec-January found a consequential downtrend in translational concentrates. Similarly the photosynthates viz., sugar (28.57mg/gm), chlorophyll (3.153 mg/gm) also show best interaction in the month of July-August in accession A35. Phenolics, however exhibited best interaction in summer (may-june) in A32 (0.39mg/gm). Table 3

Table 3

\begin{tabular}{|c|c|c|c|c|c|c|c|c|c|c|c|c|}
\hline & \multicolumn{3}{|c|}{ Protein } & \multicolumn{3}{|c|}{ Sugars } & \multicolumn{3}{|c|}{ Cholrophyll } & \multicolumn{3}{|c|}{ Phenols } \\
\hline & Summer & Rainy & Winter & Summer & Rainy & Winter & Summer & Rainy & Winter & Summer & Rainy & Winter \\
\hline Maximum & $\begin{array}{l}20.84 \\
\text { (A35) }\end{array}$ & $\begin{array}{l}21.27 \\
\text { (A18) }\end{array}$ & $\begin{array}{l}14.75 \\
\text { (A35) }\end{array}$ & $\begin{array}{l}26.71 \\
\text { (A35) }\end{array}$ & $\begin{array}{l}28.57 \\
\text { (A35) }\end{array}$ & $\begin{array}{l}20.44 \\
\text { (A35) }\end{array}$ & $\begin{array}{l}2.893 \\
\text { (A35) }\end{array}$ & $\begin{array}{l}3.153 \\
\text { (A35) }\end{array}$ & $\begin{array}{l}1.607 \\
\text { (A35) }\end{array}$ & $\begin{array}{c}0.39 \\
(\mathrm{~A} 32)\end{array}$ & $\begin{array}{c}0.31 \\
(\mathrm{~A} 40)\end{array}$ & $\begin{array}{c}0.22 \\
(\mathrm{~A} 32)\end{array}$ \\
\hline Mean & 15.08 & 18.04 & 10.44 & 20.95 & 24.95 & 13.59 & 2.063 & 2.713 & 0.972 & 0.29 & 0.199 & 0.10 \\
\hline CD (SEAS) & 3.406 & 2.897 & 3.167 & 7.462 & 3.364 & 6.97 & 0.777 & 0.6341 & 0.327 & 0.065 & 0.064 & 0.05 \\
\hline Significance & $* * *$ & $* *$ & $* *$ & $*$ & $* * *$ & NS & $* * *$ & $* * *$ & $* * *$ & $* * *$ & $* * *$ & $* * *$ \\
\hline $\mathrm{CD}(\mathrm{S} * \mathrm{~A})$ & \multicolumn{3}{|c|}{3.094} & \multicolumn{3}{|c|}{-} & \multicolumn{3}{|c|}{1.030} & \multicolumn{3}{|c|}{0.059} \\
\hline Significance & \multicolumn{3}{|c|}{$* *$} & \multicolumn{3}{|c|}{ NS } & \multicolumn{3}{|c|}{ NS } & \multicolumn{3}{|c|}{$* * *$} \\
\hline
\end{tabular}

SEAS :seasons, S*A :Season x accession, CD: Critical Difference.

Maximum correlation is observed between total soluble sugars , proteins and cholophyll (0.54 to 0.697) whereas no perceptible correlation is found between total phenols and other biochemical parameters (less than $35 \%$ ) Table 4.

Table 4: Correlation between Biochemical Parameters

\begin{tabular}{|l|c|c|c|c|}
\hline \multicolumn{1}{|c|}{ Parameters } & Total Phenol & Total Sugars & Total Protein & Total Chlorophyll \\
\hline Total Phenol & 1.000 & & & \\
\hline Total Sugars & 0.267 & 1.000 & & \\
\hline Total Protein & 0.333 & $0.543^{*}$ & 1.000 & \\
\hline Total Chlorophyll & 0.342 & $0.651^{*}$ & $0.697^{* *}$ & 1.000 \\
\hline
\end{tabular}




\section{DISCUSSION}

There are practical implications of the need to understand the variables existing within the species or a population of diverse geographical locations arising as a result of isolation or adaptation to different environmental conditions. The relative value of individual populations of a species is very difficult to judge in natural stands; therefore they were sampled and subjected to variation study in the laboratory as well as the field.

Spikes in chlorophyll content in the leaves of D. strictus in rainy season from July to August could be attributed to humid air temperature, possibly ideal for its chlorophyll biosynthesis. Kopsell and Kopsell (2003) also reported the chlorophyll biosynthesis to changing air temperature as highly species specific. The increased chlorophyll content in rainy season could also be partly due to the increased absorption of $\mathrm{Mg}^{+2}$ ion(s) the central atom amid four nitrogen atoms in a chlorophyll molecule, from soil to the root hairs. Positive correlation between rainfall and micronutrient availability has been reported by Barauh and Barauh (2000). The perceptible dip in chlorophyll pigments in low temperature winter season could be imputed to compromised pigment protein complexes eg thyllakoid membranes and subsequent photodynamic inactivation of chlorophyll due to minimal sunlight. Similar upsurges in chlorophyll content in rainy, summer and winter were reported by Senser et al., (1975) and Lewandowski and Jarvis (1977) for Sitka spruce. In a number of conifers, chlorophyll content shows maximum in summer and minimum in winter (Bourdeaeu, 1959 and Senser et al., (1975). Maximum chlorophyll content in rainy season possibly harvests more energy in the form of solar radiations converting more carbondioxide into photosynthates, thus more sugar content is obvious during the season. Also elongation and proliferation of bamboo culms takes place mainly during the rainy season, as humidity is the governing factor for growth in bamboo (Kadambi, 1949). The highest mitotic rate has to be commensurate by producing more sugars and other primary metabolites of physiological importance. The high soluble sugar content in $D$. strictus leaves in the rainy season are also associated with high catalytic activities of soluble invertases (Morris and Arthur,1985, Quick and Shaffer 1986, Ugalla et al.,2001) which convert sucrose into fructose and glucose and are later uploaded into expanding bamboo culm. The decrease in soluble sugars in winter can also be seen as a sort of adaptive strategy to enhance survivorship from seasonal pests, thus a positive correlation observed between chlorophyll content, sugar content and total soluble protein content is striking consonance with reports on other grass species by researchers. A similar high protein content in the rainy season was also found in dwarf bamboo Sassa nipponica (Yo Koyama et al., 1988). Precipitation or the amount of rainfall in a particular geographical location spells a profound impact on the vegetation of the area. In China, productivity of bamboo dramatically increases with annual rainfall (Qui et al., 1992). Yoshito et al., (2000) who evaluated the seasonal variation in dry matter production and crude protein content in Nezasa type grassland found that crude protein content of Nezasa dwarf bamboo (Pleioblastus Variegatus Makino) was 20\% more in rainy season compared to summer. Afolayan et al., (1978) also observed seasonal variation in protein content in tropical savanna grasses with the maximum protein content in the beginning of the growing season and declining towards the end. Overall, it was observed that genetic potentialities of accessions from Punjab were superior and expressed high levels of biosynthates and also displayed best interactions in rainy seasons, However, the best interaction of the season and accession on total protein content was observed in A18 from Thadugarh, Haryana (21.27 mg/g) in rainy season underscoring the favorable interplay of genes and environment. Significant variation was found with respect to phenol content the accession A32 Kahanpur (Punjab) registered the maximum yield followed by A40 from Jhelwa. Dry samples of leaf extracts registering maximum phenols in summer, could be imputed to stress conditions during high temperature conditions stimulating the synthesis of secondary metabolites such as flavonoids and phenols to combat environmentally 
induced stress on its metabolic machinery.

\section{CONCLUSION}

Dendrocalamus strictus sps is characterized by a very erratic flowering cycle and thus a need to exploit artificial breeding programs like hybridization following screening of appropriate and desirable genotypes is warranted. This would not only reduce time in plantation trials, but the concomitant increase in anticipated outcomes. The wide range of diversity observed among the accessions could, thus, be employed to affect crosses and model varieties in a desired genetic architecture. The economic traits - culm growth ,number of clumps, internode diameter and culm biochemistryare attributable to higher amounts of photosynthates and thus superior genotypes like A35 and A18 could be used as parent plant materials to acquire a desired heterotic response in future bamboo breeding programs .

\section{REFERENCES}

1. Afolayan, T.A. and Fafunsho, M. (1978). Seasonal variation in the protein content and the grazing of some tropical savanna grasses. African Journal of Ecology ., 6 (2): 97-105.

2. Baruah, A. and Baruah, K.K. (2000). Effect of rainfall on availability of micronutrient cation content in some soils of Assam. Indian J. Agri. Res., 34(2):138-140

3. Bourdeau, P.F. (1959). Seasonal variations in photosynthetic efficiency of evergreen conifers. J. Ecology., 40: 63-67.

4. Bray, H.G.and Thorpe, W.V. (1954). Analysis of phenolic compounds of interest in metabolism. In .D. Glick (ed). Methods of Biochemical Analysis, 27-52 pp.

5. Dubois, M., Gielles, K.A., Hamilton, J.K., Rebers, P.A. and Smith, F. 1956. Calorimetric method for determination of sugars and related substances. Anal.Chem., 28: 350 -356.

6. Holm, G. (1954). Chlorophyll mutation in Barley. Acta Agri. Scand., 4:457-461.

7. Kadambi, K. (1949). On the ecology and silviculture of D.strictus in the bamboo forest of Bhadrawati Division, Mysore state and comparative notes on the species of Bambusa arundinaceae, Ochlandra travancoria, Oxytenanthera monostigma and D. stocksii. Indian Forester, 75:289-299.

8. Kopsell, D.E. and Kopsell, D.A. (2004). Variation in lutein, carotene and chlorophyll concentration in Brassica oleracea cultigens and seasons. Hort. Sciences, 39:361-364.

9. Lewandowski, M. and Jarvis, P.G. (1977). Changes in chlorophyll and carotenoid content, specific leaf area and dry weight fraction in Sitka spruce, in response to shading and season. New Phytol., 79:247-256.

10. Lowry, O.H., Rosebrough, N.J., Farr, A.L. and Randall, R.J. (1951). Protein measurement with Folin phenol reagent. J. Biol. Chem., 193:265-275.

11. Mary, S.S. and Gopalan, A. (2006). Dissection of genetic attributes yield traits of fodder cowpea in $F_{3}$ and $F_{4}$. J. Applied Sci. Res., 2: 805-808

12. Morris, D.A. and Arthur, E.D. (1985). Invertase activity, carbohydrate metabolism and cell explanantion in stem of Phaseolus vulgaris L. Journal of Experimental Botany, 36:623-633.

13. Ohyama, K., Takayuki, K., Hideya, F., Tohru, S. and Kazuhiko, U. (1986). Gene organization and newly identified groups of genes of the chloroplast genome from a liverwort, Marchantia polymorpha. Photosynthesis Research., 16 (1-2): 7-22. 
14. Ollykainen, A.M. (1967). Seasonal and growth changes in the level of plastid pigments in pine needles. UCh. Zap. Petrozavodsk Gos. Univ, Chemical Abstract, 71:103-109.

15. Ollykainen, A.M. (1969). Level of carotenoids in Scots Pine needles. Byull. GI. Bot. Sada, 72:81-87.

16. Qui, F.G. (1999). The one year and off year of Phyllostachys pubescens forests and their control. J. Bamb. Res., 3(2):62-69.

17. Qui, G. X., Shen, Y. K., Li, Z. W., Wang, Q. M., Huang, D., Yang, D. and Gao, A. X. (1992). Bamboo in sub-tropical Eastern China. In: S. P. Long, M. B. Jones and M. J. Roberts (Eds)., Primary Productivity of Grass Ecosystems of the Tropics and Sub-tropics, $159-188$ pp.

18. Quick, P.and Schaffer, A.A. (1986). Sucrose metabolism in sources and sink. In: Zamski, E.and A.A. Schaffer (Eds). Photo assimilate in plants and crops, source sink relationships. Marcel Dekker, New York., 115-156pp.

19. Senser, M., Schotz, F. and Beek, E.(1975). Seasonal changes in structure and fraction of spruce chloroplast. Planta, 126:1-10.

20. Sestak, Z. (1966). Limitations for finding a linear relationship between chlorophyll content and photosynthetic activity. Biol. Plant., 8: 336-346

21. Sestak, Z. and Siffel, P. (1997). Leaf-age differences in chlorophyll fluorescence. Photosynthetica, 33: 347-369.

22. Uggala, C., Magel, E., Mortiz, T. and Sunderberg, B. (2001). Function and dynamics of auxins and carbohydrates during early wood, late wood transition in Scots pine. Plant Physiology, 125:2029-2039.

23. Yokoyama, S. and Shibata, E. (1998). The effects of sika-deer browsing on the biomass and morphology of a dwarf bamboo, Sasa nipponica, in Mt. Ohdaigahara. J. Nagoya Forest Ecology and Management, 103 (1) 6: 49-56.

24. Yoshito, Y.Y. (1999). Studies on plant succession in semi-natural grassland under some artificial pressures. J. Grassland Science, 861-1192 pp.

25. Yoshito, Y. and Nobuak, K. (2000). Growth Characteristics of Nezasa Dwarf Bamboo (Pleioblastus variegatus Makino.) and seasonal changes in dry matter production and crude protein content in Nezasa-type grassland under cattle grazing. J. Grassl and Science, 45(4): 360-366. 
